\title{
HISTÓRIA DO DESIGN
}

\section{Professora Patricia Amorim - patricia.amorim@espm.br}

ESPM - Bacharelado em Design, ênfase design visual

A graduação em Design na ESPM foi fundada em 2004. A ementa de História do Design é de autoria da diretora fundadora do curso, Ana Lúcia Lupinacci, a qual também ministrou a disciplina durante alguns anos, seguida pelo professor Celso Longo. Sou professora titular desta matéria na ESPM desde 2011.2.

Oferecida no $2^{\circ}$ semestre do curso, esta disciplina não integra uma sequência de matérias de História, embora pertença ao eixo discursivo do curso denominado Cultura e Fundamentação, ao qual também estão vinculadas disciplinas correlatas como História da Arte e Arte e Tecnologia.

Sua abordagem engloba a História do Design internacional (europeu e norteamericano) e brasileiro, percorrendo o recorte temporal que vai desde a industrialização na Inglaterra na $2^{a}$ metade do século XIX até os anos 1990. A concentração de temas é grande (Antecedentes da comunicação visual, Revolução Industrial e Historicismo, Arts \& Crafts, Art Nouveau, Vanguardas Modernistas, Art Déco, Bauhaus, Estilo Internacional, Escola de Ulm, Modernismo norte-americano, Design no Brasil, Design e pós-modernismo) e o foco no design estrangeiro acaba prevalecendo, embora eu procure sempre trazer à tona as reverberações desses processos em âmbito brasileiro.

A exploração dos temas ocorre a partir de sua contextualização socioeconômica, tecnológica e cultural e da observação de designers e de projetos, com destaque para produções no segmento do design gráfico - bem como de produto e de arquitetura - tendo em vista o caráter introdutório do curso e a necessidade de formação de repertório. Vale salientar que tópicos de História Geral e do Brasil são retomados sempre que necessário para que a compreensão do tema específico de Design aconteça da melhor maneira.

Associadas às aulas expositivas, nas quais sempre que possível utilizo trechos de documentários e filmes como recurso para ilustrar e discutir os assuntos, mais recentemente tenho intensificado as visitas com os alunos a exposições e prédios 
históricos em São Paulo, geralmente incorporando uma pequena investigação a ser realizada in loco. Nesses passeios, minha intenção é ampliar a percepção dos alunos (e minha também) sobre os temas estudados, ultrapassar os limites da sala de aula, da bibliografia e da Internet como fontes de informação e mostrar que a História do Design está viva na nossa cidade (ainda que mal conservada muitas vezes), que ela é parte importante da nossa própria História. Essas têm sido também ocasiões importantes no sentido de conhecer um pouco mais o background dos alunos e quais os espaços de cultura que eles frequentam (ou não) e o quanto conhecem e desfrutam deles na cidade.

Como formas de avaliação, são aplicadas provas sem consulta e trabalhos práticos em grupo que geralmente implicam a produção de peças gráficas e seminários. Um desses projetos, chamado Design para Ler e concebido pela professora Ana Lupinacci, envolve as disciplinas História do Design, Fundamentos de Gráfica e Comunicação e Linguagem, onde são desenvolvidos pelos alunos folders e seminários a partir da biografia e carreira de designers brasileiros. Nesses trabalhos, estimula-se as equipe a realizarem uma exploração criativa da temática histórica e elaboração de protótipos bem fundamentados e executados. As provas, entretanto, permanecem como a principal forma de verificação da aprendizagem individual e são determinantes para a definição de aprovações e reprovações.

Inserida no rol de disciplinas que compõem o núcleo básico do curso, História do Design contribui para a elaboração de uma visão histórica da atividade e de seu papel social e atua como instrumento determinante à fundamentação de projetos. Quanto à percepção dos alunos, é possível afirmar que a disciplina e minha participação nela têm sido aferidas de forma positiva, dado apontado nas avaliações docentes realizadas semestralmente na faculdade. Com os estudantes com os quais tenho uma relação mais próxima, geralmente aqueles mais interessados e dedicados ao estudos dessa matéria, é mais fácil perceber o impacto que a matéria provoca no modo de encarar seus projetos em outras disciplinas, bem como em relação a expectativas futuras de atuação profissional e acadêmica.

Em decorrência de minha atuação como docente e pesquisadora na área de História do Design, da qual minha experiência como professora desta disciplina na ESPM faz parte importante, aponto, por fim, algumas possibilidades de incremento para a disciplina, as quais pretendo explorar:

1) Conteúdo: ampliação da presença da temática da História do Design no Brasil e da América Latina no programa da disciplina;

2) Aproximação a acervos e pesquisa científica: incluir o uso de documentos de arquivos em sala de aula;

3) Ênfase no papel social e cultural: a disciplina como instrumento para a ampliação do consumo cultural e da consciência social; aproximação mais intensa dos temas da disciplina a problemas da sociedade atual;

4) Contribuição para a bibliografia da área: articulação de temas e proposta de 
novos formatos de fontes de estudo e pesquisa em função da realidade da sala de aula e dos hábitos de leitura dos alunos. 